\title{
Features of atypical granular cell tumor on fine needle aspiration in an 8-month-old child: a case report
}

\author{
Valerija Miličić ${ }^{1,2}$, Ivana Prvulović ${ }^{3}$, Marija Perići ${ }^{1}$, Branka Lončar ${ }^{1,2}$, Jasmina Rajc ${ }^{4}$, Vesna \\ Bilić-Kirin ${ }^{2,5}$
}

1. University Department of Clinical Cytology, Osijek University Hospital, Osijek, Croatia. 2. University of Osijek, School of Medicine, Osijek, Croatia. 3. Department of Cytology and Pathology, General Hospital J. Benčević, Croatia. 4. University Department of Clinical Pathology, University Hospital Center Osijek, Osijek, Croatia. 5. Institute of Public Health for the Osijek-Baranja County, Osijek, Croatia.

Correspondence: Valerija Miličić. Address: KBC Osijek, Klinički zavod za kliničku citologiju, J. Huttlera 4, Osijek, Croatia. E-mail: valerija.mj@gmail.com

Received: February 7, 2014

Accepted: April 4, 2014

Online Published: May 7, 2014

DOI: $10.5430 / \mathrm{crcp} . \mathrm{v} 1 \mathrm{n} 2 \mathrm{p} 78$

URL: http://dx.doi.org/10.5430/crcp.v1n2p78

\section{Abstract}

Granular cell tumors (GCT) are uncommon, generally benign soft tissue neoplasms that can affect virtually any site of the body, the most common locations being tongue, breast, upper respiratory tract, skin and soft tissues of upper extremities. Most patients are middle-aged, with a peak incidence in the fourth to sixth decade of life. GCT commonly presents as an asymptomatic slowly growing, painless nodule. Atypical and malignant counterparts are rare. Herein, we report on the case of an atypical GCT in an 8-months-old baby who presented at our Department with well-defined papulomatous lesion of one month duration on his back. A solitary, firm, painless nodule, about $1.5 \mathrm{~cm}$ in size was found on clinical examination. Fine needle aspiration cytology (FNAC) of the lesion was performed using a 22-gauge needle. Smears were stained with May-Grunwald-Giemsa and Papanicolaou stain. Cytomorphology revealed highly cellular tumor composed of loosely dispersed group of cells and stripped bare nuclei. The cells were large, polygonal to spindle-shaped with an abundant eosinophilic granular and fragile cytoplasm and round to oval nucleus with fine chromatin pattern. Focally cells were larger with prominent nucleoli. Rare mitotic figures were present. Diagnosis of malignant mesenchymal tumor was suggested and excision was advised. Histological examination revealed tumor tissue composed of large, polygonal cells with granular eosinophilic cytoplasm, vesicular nuclei, moderate nuclear pleomorphism and focally prominent nucleoli. There were 2 mitosis per $10 \mathrm{HPF}$. The tumor cells were positive for S-100 and vimentin. A diagnosis of atypical GCT was established. In conclusion, benign GCT has a distinctive cytomorphologic appearance and can be diagnosed on the basis of the cytological examination alone. Nuclear pleomorphism, spindling of the cells, prominent nucleoli and mitotic figures are worrisome features that suggest malignancy and necessity of histological examination. Considering the patient's age and atypical morphology, to the best of our knowledge, there have been up to $15 \mathrm{GCT}$ cases described in medical literature by now in the children less than one year.

\section{Key words}

Cytology, Atypical granular cell tumor, FNAC, Soft tissue neoplasms, Immunocytochemistry 


\section{Introduction}

Granular cell tumors are uncommon, generally benign soft tissue neoplasms that can affect virtually any site of the body. Abrikossoff ${ }^{[1]}$ is considered to be the first who described it in 1926, although its first description was made by Weber ${ }^{[2]}$ in 1854. The histogenesis of granular cell tumor (GCT) has been a source of controversy since its recognition. Granular cell tumor was initially described as myoblastoma derived from immature skeletal muscle cells, but nowadays a neural origin (probably from Schwanns cells) is supported by most authors due to the immunohistochemical pattern and electron microscopic findings ${ }^{[3-7]}$. The main morphologic feature is the granularity of the cytoplasm which is caused by a massive accumulation of lysosomes in the cytoplasm. They account for $0.5 \%$ of all soft tissue tumors ${ }^{[8]}$, and $0.017 \%-0.029 \%$ of tumors in general surgical specimens ${ }^{[9-12]}$. Although they can occur at any site, tongue, breast, upper respiratory tract, skin and soft tissue of upper extremities are their common locations ${ }^{[9-19]}$. The head and neck region accounts for approximately $45 \%-65 \%$ of all sites for GCT ${ }^{[20]}$. Granular cell tumors affect persons of different age but mostly patients are middle-aged, with a peak incidence in the fourth to sixth decades of life ${ }^{[21]}$. A slight male predominance exists, with an estimated male-to-female ratio of approximately 2-3:1 ${ }^{[22]}$. These tumors are usually solitary, but multiple satellite nodules are present in 10 to $15 \%$ of all cases ${ }^{[23]}$. Multiple GCTs are reported in association with neurofibromatosis, Watson's syndrome, Lentiginosis profusa, Noonan syndrome, facial and ocular alterations and cardiovascular abnormalities. Granular cell tumors can be benign, atypical and malignant. Atypical variants have an excellent outcome with no metastases. The malignant ones have approximately $40 \%$ risk of death causing.

Herein, we report the case of atypical GCT in an 8-month-old baby. In regard to the patient's age and atypical morphology, to the best of our knowledge, there have been up to $15 \mathrm{GCT}$ cases described in medical literature by now in the children less than one year.

\section{Case presentation}

\subsection{Materials and methods}

Fine needle aspiration cytology (FNAC) was performed by a 22-gauge needle. Smears were stained with May-GrunwaldGiemsa and Papanicolaou method. Excisional bioptic material was fixed overnight in $10 \%$ buffered formaline. Tissue was embedded in paraffin; $3 \mu \mathrm{m}$ thick sections were cut and stained using H\&E. Immunohistochemical studies were performed by peroxidase avidin-biotin method using the formalin fixed and paraffin embedded material. The following primary antibodies have been used: S-100, vimentin, SMA, actin, MSA, CD34, chromogranin, melan A, CK AE1/AE3, CD 68, neurofilament, GFAP, desmin, Ki-67.

\subsection{Case report}

An 8-month-old baby, born prematurely, presented at our Department with well-defined papulomatous lesion of one month duration on the back. A solitary, firm, painless nodule, about $1.5 \mathrm{~cm}$ in size was found on clinical examination (see Figure 1). FNA was performed. The smears were highly cellular composed of loosely dispersed group of cells and stripped bare nuclei. The cells were large, polygonal to spindle-shaped with an abundant, eosinophilic granular and fragile cytoplasm and round to oval nucleus with fine chromatin pattern. Focally, cells were even larger with prominent nucleoli. Mitotic figures were present (see Figure 2-4). A cytologic diagnosis of malignant fibrous histiocytoma was made and excision was advised. Histopathological examination of the excised tissue revealed tumor consisting of large, polygonal cells with copious, granular eosinophilic cytoplasm, vesicular nuclei with focally prominent nucleoli and moderate nuclear pleomorphism. Two mitoses per 10 high power fields have been found (see Figure 5). Immunohistochemically, the tumor cells were positive for S-100 protein and vimentin, and negative for SMA, actin, MSA, CD34, chromogranin, melan A, cytokeratin AE1/AE3, CD 68, neurofilament, GFAP, desmin. The proliferative index with Ki-67 was 1\%. A diagnosis of atypical GCT was established (see Figure 6, 7). 
Figure 1. Macroscopic appearance of the tumor

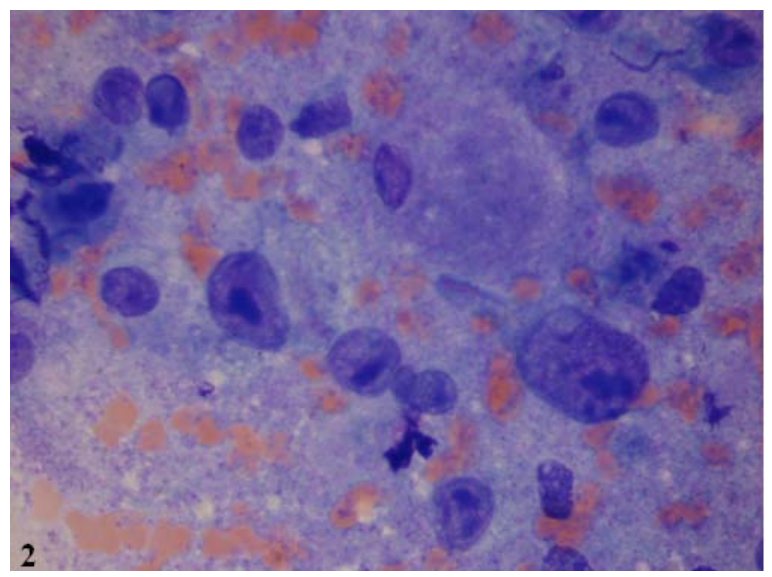

Figure 2. The tumor cells show polymorphism, occasionally spindle shape and prominent nucleoli. May-Grünwald-Giemsa, $\times 400$.

Figure 3. The cells of granular cell tumor are polygonal, with nuclei ranging from small to large with vesicular chromatin and sometimes prominent nucleoli. MayGrünwald-Giemsa, $\times 400$.

Figure 4. The tumor cells show moderate amounts of nuclear atypia, slightly spindled in character with occasionally prominent nucleoli. May-Grünwald-Giemsa, $\times 400$.

Figure 5. The tumor cells have large, eosinophilic, fine granulated cytoplasm with eccentrically located prominent nucleoli and mitosis. Hematoxylin, eosin $\times 400$.
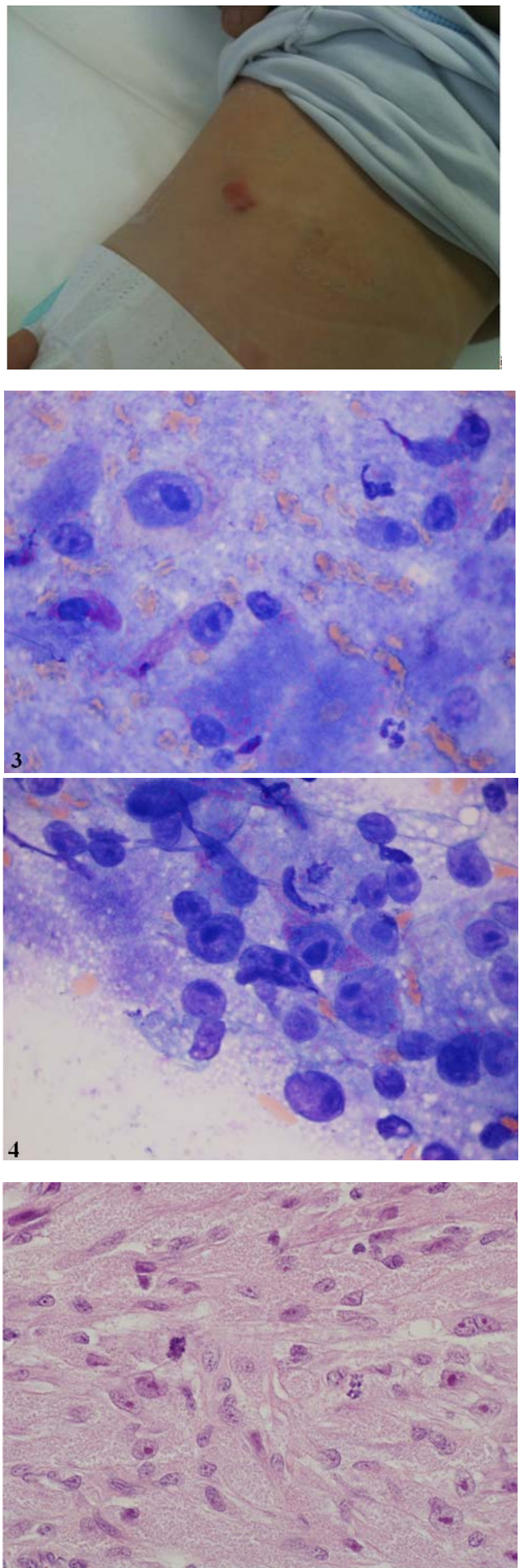

ISSN 2331-2726 E-ISSN 2331-2734 


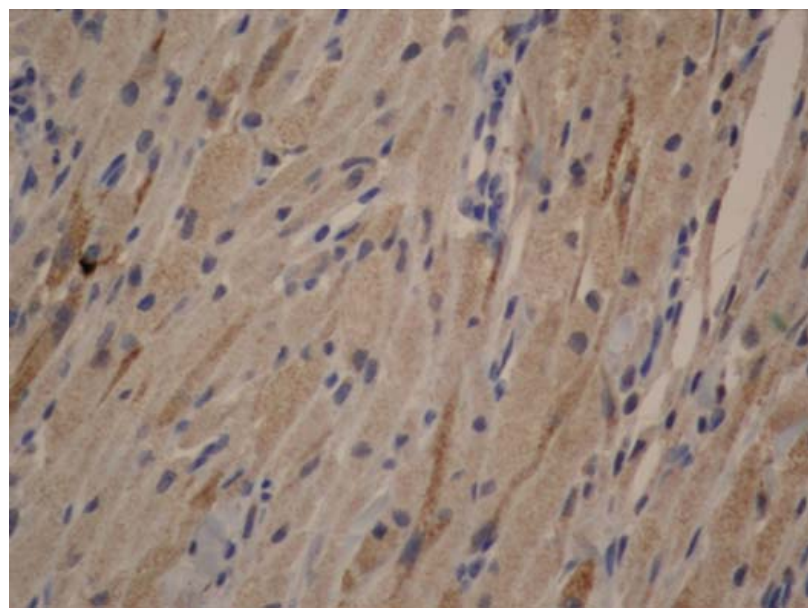

Figure 6. Immunostaining: S100, $\times 400$

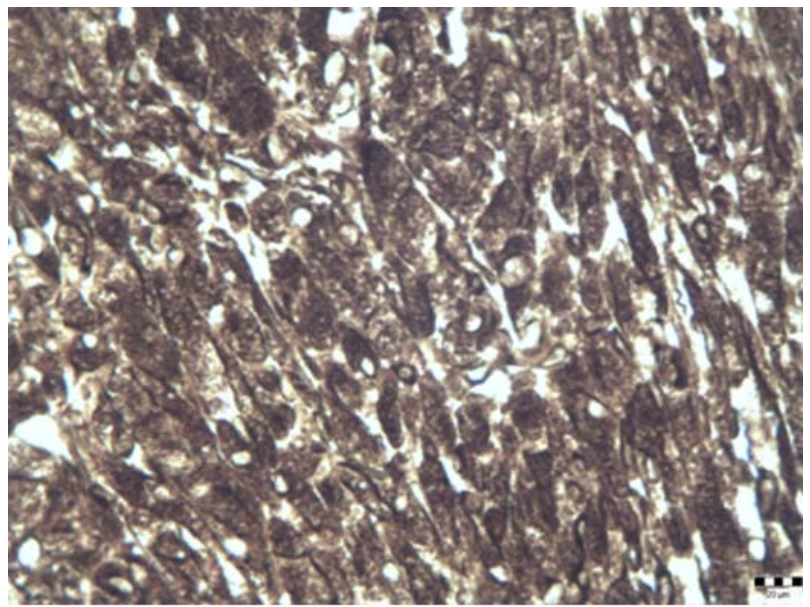

Figure 7. Immunostaining: Vimentin, $\times 400$

\section{Discussion}

In skin location, GCT commonly presents as an asymptomatic slowly growing, solitary, painless nodule with either smooth or hyperkeratotic overlying skin ${ }^{[11,12,15,16]}$. The lesions are usually smaller than $3.0 \mathrm{~cm}$ and may undergo partial regression ${ }^{[12,15]}$.

About $2 \%$ of all granular cell tumor cases are malignant ${ }^{[24-27]}$. A tumor $3 \mathrm{~cm}$ or less in size can be regarded as benign. However, rapid tumor growth and ulceration are indicative for malignancy.

On FNAB, benign GCT has a distinctive cytomorphologic appearance that permits its diagnosis. The smears are usually highly cellular and characterized by polygonal cells in cohesive groups as well as single cells, with eccentric, round to slightly oval nuclei and abundant, finely granular cytoplasm. The cells are fragile, with stripped nuclei in the background of finely granular material. Occasional cells with nuclear polymorphisms and small but conspicuous nucleoli could be seen ${ }^{[28-32]}$. Liu et al. ${ }^{[32]}$ pointed out that focal nuclear polymorphisms and prominent nucleoli are still compatible with benignancy. This could represent a problem in cytological differentiation between benign and atypical or eventually malignant cases in comparison to histological classification where the criteria are well defined.

Fanburg-Smith et al. ${ }^{[25]}$ classified atypical, malignant, and benign granular cell tumors on the basis of six histologic criteria: necrosis, spindling, vesicular nuclei with large nucleoli, increased mitotic activity $(>2$ mitoses/10 high power fields at $\times 200$ magnification), high nuclear to cytoplasmic ratio, and pleomorphism. Neoplasms that met three or more of these criteria were classified as histologically malignant, those that met one or two criteria were classified as atypical, and those that displayed only focal pleomorphism, but fulfilled none of the other criteria, were classified as benign. In our case, the tumor met 2 of 6 criteria for diagnosis (vesicular nuclei and pleomorphism).

Sonobe and colleagues ${ }^{[26]}$ divided malignant granular cell tumors into two groups: those that are malignant both histologically and clinically, and those that are histologically benign but clinically malignant.

The most common metastatic sites of malignant granular cell tumor are lymph nodes, followed by the lungs. Surgical excision with safe margins is recommended due to ill-defined margins and risk of recurrence ${ }^{[10-12,17]}$. Incomplete tumor excision often results in local recurrence, and eventual tendency to spread both lymphogenously and hematogenously. This emphasizes the need of recognizing this lesion on FNAC, so an adequate curative excision may be properly planned. Morphologically, on FNAB the differential diagnoses of GCT may include inflammatory lesions with numerous histiocytes, malignant fibrous histiocytoma, oncocytic neoplasms, neuroendocrine tumors, granular renal cell carcinoma, 
leiomyosarcoma, melanoma and ameloblastoma ${ }^{[28,29,33,34]}$. In our case we incorrectly diagnosed aGCT as malignant fibrous histiocytoma. Malignant fibrous histiocytoma is a heterogeneous group of malignant myofibroblasticfibrohistiocytic tumors, with well-defined storiform-pleomorphic, myxoid, giant cell-rich, and inflammatory morphological variants. We were misled by pleomorphism and spindle shaped cells, and we didn't give sufficient importance to granular and fragile cytoplasm and numerous naked nuclei.

Immunocytochemical stains are helpful in establishing of proper diagnosis. S-100 protein, neurone-specific enolase, markers of neural origin and vimentin are usually expressed in this tumor ${ }^{[12]}$, while epithelial, melanocytic, smooth muscle, dendritic cell and endothelial markers are negative in this tumor.

In our case, the cytological diagnosis acquired a great significance since it was the case of a child with high risk for neurological disorders caused by three-month premature delivery. The clinician did not want to take the risk of a surgical procedure without a good reason. The cytological diagnosis was expected to provide a definite confirmation of the benignancy which would postpone the surgery until the acceptable stability of the baby's condition.

\section{Conclusion}

Herein, we report on a case of extremely rare atypical GCT in 8-month-old child. In regard to the patient's age and atypical morphology, to the best of our knowledge, there have been up to $15 \mathrm{GCT}$ cases described in medical literature by now with children less than one year old.

Benign GCT has a distinctive cytomorphologic appearance and can be diagnosed on basis of the cytological examination alone. Specimens with any signs of cells pleomorphism or any other kind of atypia need further histological examination, because cytological examination can not distinguish between atypical and malignant granular cell tumors.

\section{Acknowledgement}

The authors express deep and sincere gratitude to Dr. Gorana Gašljević whose suggestion and very constructive criticism have contributed processing this manuscript.

\section{References}

[1] Abrikossoff A. On Myoma on skeletal muscles. Virchows Arch Pathol Anat. 1926; 260: 215-233. http://dx.doi.org/10.1007/BF02078314

[2] Weber CO. Anatomical study of hyper-trophic tongue in addition to neoplasm of skeletal muscles. Virchow Arch Pathol Anat. 1854; 7: 115. http://dx.doi.org/10.1007/BF01936232

[3] Mallik MK, Das DK, Francis IM, Al-Abdulghani R, Pathan SK, Sheikh ZA, et al. Fine needle aspiration cytology diagnosis of a cutaneous granular cell tumor in a 7-year-old child. A case report. Acta Cytol. 2001; 45(2): 263-6. PMid: 11284316. http://dx.doi.org/10.1159/000327287

[4] Mukai M. Immunohistochemical localization of S-100 protein and peripheral nerve myelin proteins (P2 protein, PO protein) in granular cell tumors. Am J Pathol. 1983; 112: 139-146. PMid: 6192721.

[5] Kurtin PJ, Bonin DM. Immunohistochemical demonstration of the lysosome-associated glycoprotein CD68 (KP-1) in granular cell tumors and schwannomas. Hum Pathol. 1994; 25: 1172-8. http://dx.doi.org/10.1016/0046-8177(94)90033-7

[6] Pathania K, Bhargava S. Granular cell tumour of breast: A mimic of carcinoma. MJAFI. 2010; 66: 292-4.

[7] Ordonez NG. Granular cell tumor: a review and update. Adv Anatomic Pathol. 1999; 6: 186-203. http://dx.doi.org/10.1097/00125480-199907000-00002

[8] Aoyama K, Kamio T, Hirano A, Seshimo A, Kameoka S. Granular cell tumors: a report of six cases. World J Surg Oncol. 2012; 10: 204. http://dx.doi.org/10.1186/1477-7819-10-204

[9] Price MF, Paletta CE, Woodberry KM. Granular cell tumor in a child's finger. Ann Plast Surg. 2000; 44: 447-50. PMid: 10783106. http://dx.doi.org/10.1097/00000637-200044040-00018 
[10] Elkousy H, Harrelson J, Dodd L, Martinez S, Scully S. Granular cell tumors of the extremities. Clin Orthop Relat Res. 2000; 380: 191-8. PMid: 11064991. http://dx.doi.org/10.1097/00003086-200011000-00026

[11] Korambayil PM. Granular cell tumour of the hand. Indian J Plast Surg. 2012; 45: 160-2. PMid: 22754179. http://dx.doi.org/10.4103/0970-0358.96600

[12] Agarwal A, Sinha A, Rijal A, Karki S, Nizamani SM. Cytology diagnosis of granular cell tumor of umbilicus mimicking metastatic skin nodule and review of literature. MedChannel. 2010; 16: 103-105.

[13] Chung SY, Noh WC, Jin MS, Lee SS, Koh JS. Fine needle aspiration cytology of granular cell tumor in breast -A case report. Korean J Cytopathol. 2007; 8: 157-60.

[14] Singh A, Sawhney M, Sushruta Das. Granular Cell Tumor of Skin Diagnosed on Fine Needle Aspiration Cytology. Indian J Dermatol. 2012; 57(4): 330-331. http://dx.doi.org/10.4103/0019-5154.97690

[15] Maladry D, Revol M, Servant JM, Banzet P. Abrikossoff's tumor of the hand. Apropos of a case. Review of the literature. Ann Chir Main Memb Super. 1991; 10: 167-70. http://dx.doi.org/10.1016/S0753-9053(05)80203-0

[16] Loncar B, Marjanovic K, Pauzar B, Staklenac B. Granular cell tumor-clinically presented as lymphadenopathy. Coll Antropol. 2010; 34: 261-3. PMid: 20432759.

[17] Sung JW, Choi JH. Imprint cytology of granular cell tumor-A case report. Korean J Cytopathol. 2007; 8: 170-74.

[18] Usui M, Ishii S, Iwasaki K. Granular cell tumour of the hand. Hand. 1982; 14: 329-32. http://dx.doi.org/10.1016/S0072-968X(82)80070-3

[19] Slutsky DJ. Granular cell nerve tumor in the hand: Case report. J Hand Surg Am. 2009; 34: 1512-4. http://dx.doi.org/10.1016/j.jhsa.2009.05.011.

[20] Buick RG. Granular Cell Tumors, Meducation, accessed 13.3.2013. Available from: https:/www.meducation.net/files/high_quality/584.swf

[21] Barbieri M, Musizzano Y, Boggio M, Carcuscia C. Granular cell tumour of the tongue in a 14-year-old boy: case report. Acta Otorhinolaryngol Ital. 2011; 31(3): 186-9. PMid: 22058595.

[22] Qureshi NA, Tahir M, Carmichael AR. Granular cell tumour of the soft tissues: a case report and literature review. Int Semin Surg Oncol. 2006; 3: 21. PMid: 16930486. http://dx.doi.org/10.1186/1477-7800-3-21

[23] Lack EE, Worsham GF, Callihan MD, Crawford BE, Klappenbach S, Rowden G, et al. Granular cell tumor: a clinicopathologic study of 110 patients. J Surg Oncol. 1980; 13: 301-16. PMid: 6246310. http://dx.doi.org/10.1002/jso.2930130405

[24] Khansur T, Balducci L, Tavassoli M. Granular cell tumor. Clinical spectrum of the benign and malignant entity. Cancer. 1987; 60: 220-222. http://dx.doi.org/10.1002/1097-0142(19870715)60:2<220::AID-CNCR2820600217>3.0.CO;2-V

[25] Fanburg-Smith JC, Meis-Kindblom JM, Fante R, Kindblom LG. Malignant granular cell tumor of soft tissue: diagnostic criteria and clinicopathologic correlation. Am J Surg Pathol. 1998; 22: 779-794. PMid: 9669341.

http://dx.doi.org/10.1097/00000478-199807000-00001

[26] Sonobe H, Iwata J, Furihata M, Moriki T, Ohtsuki Y. Malignant granular cell tumor: report of a case and review and the literature. Pathol Res Pract. 1998; 194: 507-513. http://dx.doi.org/10.1016/S0344-0338(98)80119-2

[27] Kataoka A, Koike M, Kuranuki K, Wakayama K, Yamada S, Akasaka Y. A case of malignant granular cell tumor arisen in the chest wall (in Japanese with English abstract). J Jpn Surg Assoc. 2005; 66: 2403-2406. http://dx.doi.org/10.3919/jjsa.66.2403

[28] Osipov VO, Shidham VB. Granular Cell Tumors. Emedicine. accessed 8.1.2013. Available from: URL:http://emedicine.medscape.com/article/282430-overview

[29] Gupta R, Singh S, Jain S, Mandal K. Granular cell tumour of the subcutis: a cytological diagnosis. Cytopathology. 2005 ; $16: 318$. PMid: 16303050. http://dx.doi.org/10.1111/j.1365-2303.2005.00278.x

[30] Wieczorek TJ, Krane JF, Domanski HA, Akerman M, Carlen B, Misdraji J, et al. Cytologic findings in granular cell tumors, with emphasis on the diagnosis of malignant granular cell tumor by fine-needle aspiration biopsy. Cancer Cytopathology. $2001 ; 93: 398$. PMid: 11748580. http://dx.doi.org/10.1002/cncr.10143

[31] Policarpio-Nicolas MLC, Lee BH, Mandell JW, Lopes BMS. Granular cell tumor of the neurohypophysis: Report of a case with intraoperative cytologic diagnosis. Diagnostic Cytopathology. 2008; 36: 58. PMid: 18064694. http://dx.doi.org/10.1002/dc.20646

[32] Liu K, Madden JF, Olatidoya BA, Dodd LG. Features of benign granular cell tumor on fine needle aspiration. Acta Cytol. 1999; 43: 552. PMid: 10432874. http://dx.doi.org/10.1159/000331146

[33] Perić M, Milicić V, Pajtler M, Marjanović K, Zubcić V. Potential value and disadvantages of fine needle aspiration cytology in diagnosis of ameloblastoma. Coll Antropol. 2012; 36(2): 147-50. PMid: 23397775.

[34] Seili-Bekafigo I, Jonjić N, Stemberger C, Rajković-Molek K. Additional cytomorphological criteria in diagnosis of pilomatricoma-benign tumor with bad reputation. Coll Antropol. 2010; 34(1): 117-22. PMid: 20432739. 